\title{
Trephine Stoma Creation Under Local Anesthesia with Sedoanalgesia
}

\section{Sedoanaljezi Eşliğinde Lokal Anestezi Altında Trefin Stoma Uygulaması}

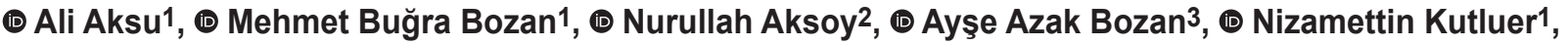

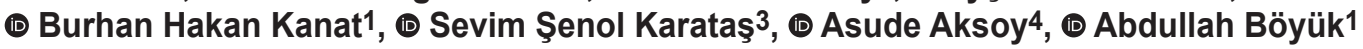

\author{
1 University of Health Sciences, Elazığ Training and Research Hospital, Clinic of General Surgery, Elazığ, Turkey \\ 2Şanlıurfa Siverek State Hospital, Clinic of General Surgery, Şanlıurfa, Turkey \\ 3University of Health Sciences, Elazığ Training and Research Hospital, Clinic of Anesthesiology and Reanimation, Elazığ, Turkey \\ ${ }^{4}$ Fırat University Faculty of Medicine, Department of Oncology, Elazığ, Turkey
}

\section{HIIIIII| ABSTRACT}

Aim: In this paper, we aimed to evaluate the patients who underwent trephine stoma with sedoanalgesia in addition to local anesthesia and to share the results.

Method: The patients who underwent trephine stoma with sedoanalgesia in addition to local anesthesia for fecal diversion in our general surgery clinic between June 2012 and June 2017 were evaluated retrospectively. The patients were evaluated in terms of demographic characteristics, diagnosis of primary disease and complications.

Results: A total of 11 patients (F/M: 4/7) were evaluated. The mean age was $54( \pm 4)$ years. The mean follow-up period was 18 months (range 2-30). Primary disease was rectal cancer in seven patients (63.6\%), Fournier's disease in two patients (18.2\%), genital cancer in one patient (9.1\%), and rectovaginal fistula in one patient $(9.1 \%)$. Only one patient underwent transverse colostomy and 10 patients underwent sigmoid colostomy. There were no complications related to surgical procedures. One patient died on the $14^{\text {th }}$ postoperative day because of complications secondary to metastasis. Conclusion: Trephine stoma technique, which does not require laparotomy, is a fast, reliable, and easy to use method especially in high-risk patients with poor general condition.

Keywords: Colostomy, emergent surgery, local anesthesia, minimally invasive surgery, trephine stoma

\section{|||||||||| ÖZ}

Amaç: $\mathrm{Bu}$ yazıda lokal anesteziye ilave olarak sedoanaljezi ile trefin stoma uyguladığımız hastaları değerlendirmeyi ve sonuçlarını paylaşmayı amaçladık.

Yöntem: Haziran 2012-Haziran 2017 tarihleri arasında genel cerrahi kliniğimizde fekal diversiyon amacıyla sedoanaljezi yardımlı lokal anestezi eşliğinde trefin stoma uygulaması yapılan hastalar retrospektif olarak incelendi. Hastalar demografik özellikleri, primer hastalığın tanısı ve komplikasyonlar açısından değerlendirildi.

Bulgular: Toplam 11 (K/E: 4/7) hastanın verileri değerlendirildi. Ortalama yaş 54 ( \pm 4 ) yıl idi. Ortalama takip süresi 18 ay (2-30 arasında) idi. Hastaların primer hastalıkları 7 hastada rektum kanseri (\%63,6), 2 hastada Fournier hastalığı $(\% 18,2), 1$ hastada genital kanser $(\% 9,1), 1$ hastada rektovajinal fistül $(\% 9,1)$ idi. Yalnızca 1 hastaya tranvers kolostomi, 10 hastaya ise sigmoid kolostomi uygulandı. Girişimsel işleme bağlı herhangi bir komplikasyon gelişmedi. Bir hasta postoperatif 14. günde metastaza sekonder komplikasyonlar nedeniyle öldü.

Sonuç: Özellikle genel durumu iyi olmayan, yüksek riskli hastalarda, laparatomi gerektirmeyen trefin stoma tekniği hızlı, güvenilir, kolay uygulanabilen bir yöntemdir.

Anahtar Kelimeler: Kolostomi, acil cerrahi, lokal anestezi, minimal invaziv cerrahi, trefin stoma

University of Health Sciences, Elazığ Training and Research Hospital, Clinic of General Surgery, Elazı̆̆, Turkey

Phone: +90 5303415044 E-mail: bbozan@yahoo.com ORCID ID: orcid.org/0000-0001-5573-2645

Received/Gelis Tarihi: 22.10.2018 Accepted/Kabul Tarihi: 28.10.2018 


\section{Introduction}

In colorectal surgery, stoma applications are the process of opening the intestinal tract to the abdominal wall. The history of surgical stoma dates back 200 years. ${ }^{1}$ Stomas can be either temporary or permanent and their indications are very various. In colorectal surgery, the stoma is mostly performed for incontinence requiring fecal diversion, Fournier's gangrene, complex anorectal fistulas, anorectal trauma, and obstructed anorectal tumors. The techniques for the creation of stomas for fecal diversion may vary depending on the indication and the condition of the patient. ${ }^{2}$ The most important determinants for the selection of the type of stoma are the location of the stoma, the technique used, and the characteristics of the patient. ${ }^{1}$ This procedure is usually done by laparotomy, but it can also be performed without a laparotomy.

Trephine stoma technique is a less invasive procedure without laparotomy. Trephine as a medical term means the removal of a tissue by circular incision. In this technique, a circular incision is made to the previously determined area in the abdominal wall and a stoma is created with the intestines brought from the abdomen. It is a method that can be preferred especially in patients with poor general condition, comorbidity and complication.

In the literature, there are some articles related to this technique and the procedure was performed under general anesthesia or regional anesthesia in most of them. In our clinic, the application was performed with sedoanalgesia in addition to local anesthesia. In this paper, we aimed to evaluate the patients who underwent trephine stoma with sedoanalgesia in addition to local anesthesia and to share the results.

\section{Materials and Methods}

The patients who underwent trephine stoma with sedoanalgesia in addition to local anesthesia for fecal diversion in our general surgery clinic between June 2012 and June 2017 were retrospectively evaluated. Data of the patients were obtained from personal records and computer records. Patients with missing data were excluded from the study. A total of 11 patients were included in the study. The patients were evaluated in terms of demographic characteristics, diagnosis of primary disease and complications. All patients were consulted with the anesthesia clinic as routine procedure and the risks of anesthesia were determined.

\section{Statistical Analysis}

Statistical analysis of the study was performed using SPSS 20 (SPSS for Windows, Inc., Chicago, IL, USA). Data were presented as percentage and arithmetic mean \pm standard deviation (minimum-maximum).

\section{Technique}

The procedure was performed under sterile conditions in the operating room. Colostomy area was marked in the left lower quadrant while the patients were sitting, standing and lying. After a single dose of antibiotic prophylaxis, the patient was draped and prepped as if laparotomy was to be performed. All patients received nasal oxygen at 2 liters/min during the procedure. All medications were administered intravenously.

Initially, all patients were administered midazolam 0.05 $\mathrm{mg} / \mathrm{kg}$ and fentanyl $1 \mathrm{mcg} / \mathrm{kg}$ by anesthesiologist. Ramsay sedation scale that was developed by M. A. Ramsay in the mid-1970s was used to determine the level of sedation of patients. ${ }^{3}$ Ramsay score of the patients was kept between 3-4. This scale consists of a total of six items, each of which contains three levels of awake and asleep. ${ }^{4}$ These are as follows: patient awake, anxious, agitated, or restless; patient awake, cooperative, orientated, and tranquil; patient drowsy, with response to commands; patient asleep, brisk response; patient asleep, sluggish response and patient has no response. The first three responses are evaluated in the awake patient, and the other three responses are evaluated by glabella tap or loud auditory stimulus. Midazolam 0.03 $\mathrm{mg} / \mathrm{kg}$ and fentanyl $0.5 \mathrm{mcg} / \mathrm{kg}$ IV were administered when additional dose was needed.

While the patient was sedated, rectus muscle and sheath were infiltrated with lidocaine or bupivacaine. Lidocaine is faster, but short-acting, while bupivacaine is slower and much longer effective. The dose limitation for both is independent of each other. The recommended dose by the Food and Administration is $7 \mathrm{mg} / \mathrm{kg}$ for lidocaine. The maximum reported dose range is $200-300 \mathrm{mg}$. The maximum dose for bupivacaine is $175 \mathrm{mg}$. If adrenaline is added, these can be increased up to 500 and 225 milligrams. $^{5}$

Local anesthesia including intradermal, subdermal and deep subcutaneous is performed in the previously marked area. An elliptical incision in normal colostomy size is used to pass the skin and subcutaneous fascias to reach the fascia of the left rectus muscle. Next, local anesthetic agent infiltration is performed on the lateral of the rectus abdominis muscle toward the aponeurosis of the internal, external oblique and transversus abdominis muscle. After the fascia is incised, the muscles are opened and the peritoneum is reached. At this stage, the intestinal loop is taken out of the opening by Babcock clamp (loop colostomy) and the baguette is passed. The colostomy mouth is then sutured (Figure 1).

\section{Results}

The data of 11 patients included in the study were evaluated. The mean age of the patients was $54 \pm 4$ years (range: $37-81$ ). 
Four of the patients were female (36\%) and seven were male (64\%). Regarding primary diagnosis, seven patients had rectal cancer (63.6\%), two patients had Fournier's disease (18.2\%), one patient had genital cancer (9.1\%), and one patient had rectovaginal fistula (9.1\%). Six patients $(54.5 \%)$ had comorbidities, including diabetes mellitus, ischemic heart disease, chronic obstructive pulmonary disease, and other organ metastases due to the rectum tumor (lung, liver, adrenal). Only one patient underwent transverse colostomy and 10 patients underwent sigmoid colostomy. Five of the patients with rectal cancer had complete obstruction and 2 patients had partial obstruction. These 7 patients were

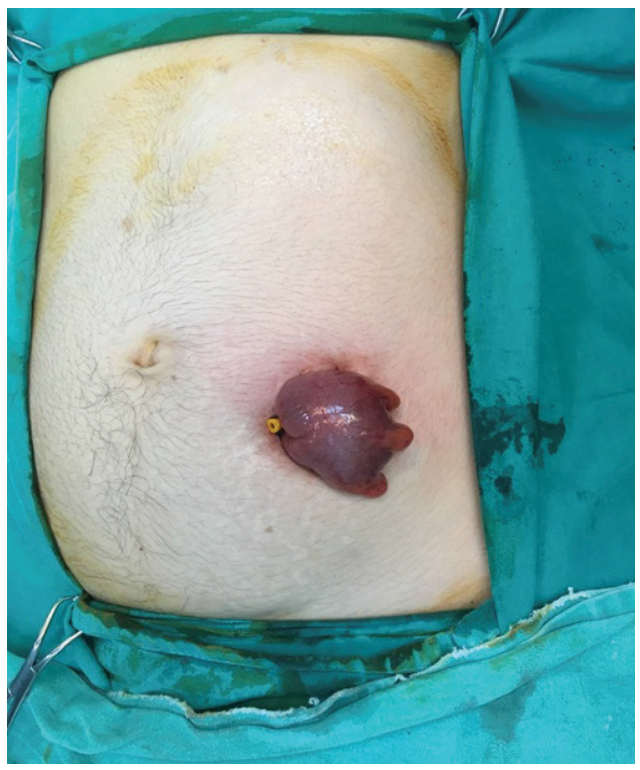

Figure 1. The patient who underwent trephine stoma treated under emergency conditions and the other patients were treated electively. No complication was observed in any patient due to interventional procedures. One patient died on the $14^{\text {th }}$ postoperative day because of complications secondary to metastasis. The mean follow-up period was 18 months (range: 2-30) (Table 1).

No anesthetic drug-related complication was observed during or after the procedure. Wound site infection developed in one patient who had ostomy due to Fournier's gangrene. In all patients, oral intake was started on the $1^{\text {st }}$ postoperative day. No postoperative ileus was observed in any patient. Three of the patients who underwent ostomy due to rectal cancer were operated laparoscopically during the follow-up period.

\section{Discussion}

Stoma is a Greek word meaning "opening" or "mouth". Intestinal stoma means that the intestine is mouthed on the abdominal wall. It is divided into two, as permanent or temporary. Furthermore, it is classified as end ileostomy (Brooke ileostomy), loop ileostomy, continent (Kock) ileostomies, loop colostomy, double-barrel colostomy (Mikulicz), Hartmann's procedure, and permanent end colostomy according to opening type. ${ }^{6}$

Stomas can be opened with laparotomy or laparoscopy or without laparotomy. Trephine stoma technique, which is opened without laparotomy, was first described by Senapati. Trephine stoma technique can be performed as ileostomy or colostomy. ${ }^{2,7}$ Trephine stoma technique, which does not require laparotomy in high-risk patients, is a fast, reliable and easy to use method. Previous abdominal surgery is

Table 1. The characteristics of the patients

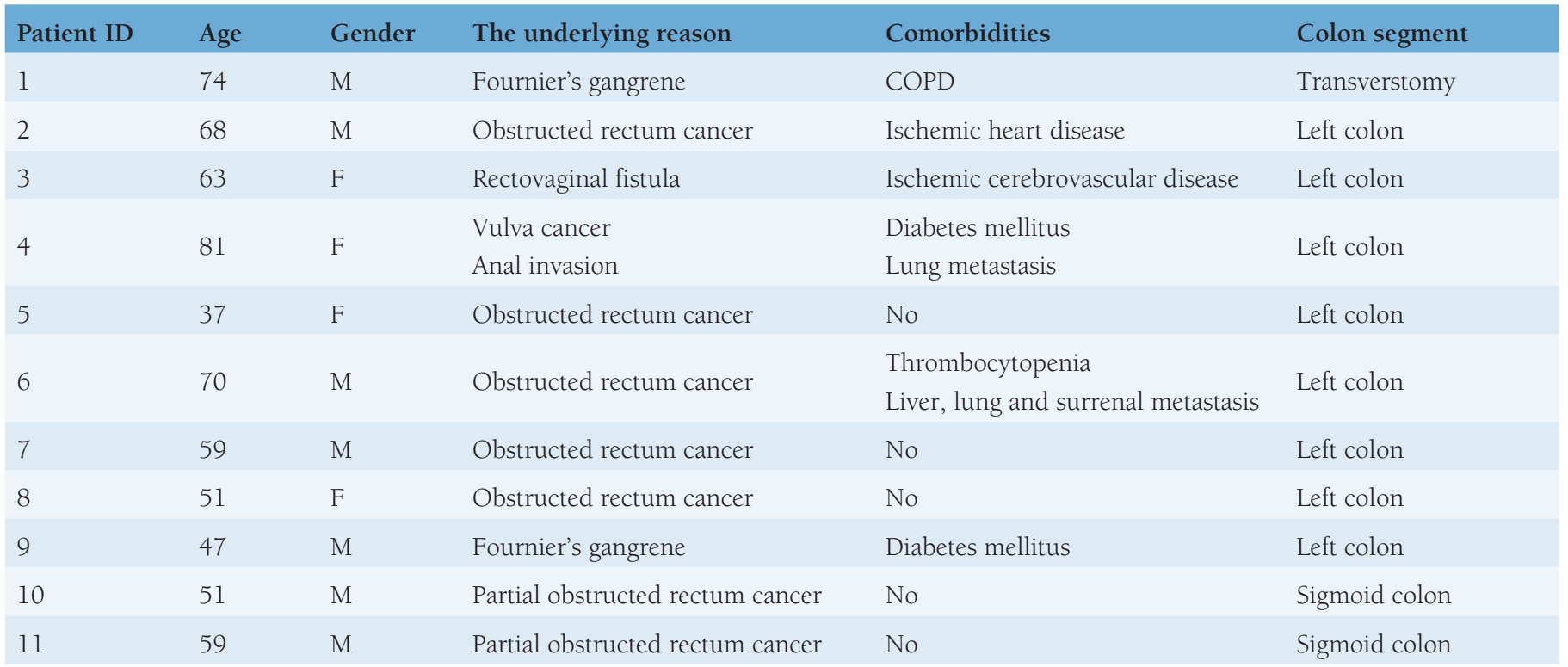

M: Male, F: Female, COPD: Chronic obstructive pulmonary disease 
usually not a contraindication. The operation time is shorter and the postoperative opiate requirement is less than the stoma performed by laparotomy. ${ }^{6}$ Trefin stoma is a simple, fast and the least invasive technique among the techniques of stoma creation. Because there is no separate laparotomy incision in the abdomen, postoperative recovery is faster and pain is minimal. ${ }^{7}$ However, it may rarely be difficult to determine the proximal and distal part of the intestine. We encountered this difficulty in our patient with genital cancer and colonoscopy was performed to determine the parts during surgery. ${ }^{8}$ Another topic of discussion is the length of the incision when creating the trephine stoma. In a study, it is stated that this length should be two-thirds of the stoma. ${ }^{9}$ The length of our incisions was the same as stoma length.

In a study on trephine stoma performed in cases with sigmoid volvulus, sigmoid colon was taken out of the body by a small incision under general anesthesia and resection was performed. Then, trephine stoma was performed. ${ }^{10}$ The most important problem of this study is the need for general anesthesia. In our study, which had small number of patients, none of the patients had sigmoid volvulus.

In the literature, there are many articles about the trephine stoma technique and most of them were performed under general anesthesia. ${ }^{11,12,13}$ Also, laparoscopic assisted trephine stoma technique was performed. ${ }^{13}$ The most important difference of our study from other studies was that it was performed under sedoanalgesia in addition to local anesthesia.

\section{Conclusion}

In patients with a high risk of anesthesia, trephine stoma creation under sedoanalgesia does not cause an additional morbidity burden due to the lack of endotracheal intubation. Also, no need for laparotomy causes less intra-abdominal adhesion in patients with rectal cancer who are candidates for neoadjuvant chemotherapy and facilitates subsequent laparoscopic surgery. Therefore, this method should be kept in mind in patients with rectum cancer or anorectal diseases requiring diversion and should be performed if necessary.

\section{Ethics}

Ethics Committee Approval: Retrospective study.

Informed Consent: Retrospective study.
Peer-review: Externally peer-reviewed.

\section{Authorship Contributions}

Surgical and Medical Practices: A.A., B.H.K., M.B.B., Concept: B.H.K., M.B.B., N.K., A.B., Design: N.K., A.A.B., N.A., A.B., Data Collection or Processing: A.A.B., N.K., S.Ş.K., A.Aksoy., Analysis or Interpretation: M.B.B., B.H.K., A.A.B., A.A., Literature Search: A.Aksoy., S.S..K., N.A., B.H.K., M.B.B., Writing: B.H.K., M.B.B., A.A., N.K., A.A.B.

Conflict of Interest: No conflict of interest was declared by the authors.

Financial Disclosure: The authors declared that this study received no financial support.

\section{References}

1. Kapan M, Girgin S, Keleş C, Önder A, Gümüş M. Kolorektal cerrahide ostomi uygulamaları. Türkiye Klinikleri J Gastroenterohepato 2010;17:94106

2. Oğuz A, Türkoğlu A, Gümüş M, Bozdağ Z, Bahadır MV, Teke F, et al. Trephine stoma: Outcomes in a single center. J Clin Exp Invest 2015;6:8790.

3. Detriche O, Berre J, Massaut J, Vincent LJ. The Brussels sedation scale: use of a siple clinical sedation in patients undergoing mechanical ventilation in the intensive care. Br J Anaesth 1999;83:698-701.

4. Şahinoğlu AH. Yoğun bakımın doğuşu, gelişmesi ve genel ilkeler. İn Yoğun Bakım Sorunları ve Tedavi İlkeleri. Ed. 1. Baskı, Ankara, Türkiye Klinikleri Yayınevi. 1992:3-4.

5. Kulaçoğlu H. Kasık fitıklarının cerrahi tedavisinde adım-adım lokal anestezi tekniği "Teknik Not". Turk J Surg 2012;28:164-168.

6. Akgün EZ, Yoldaş $T$. İntestinal Stoma. Kolon Rektum Hast Derg 2012;22:133-146

7. Neşşar G, Kayaalp C, Bil D, Karadağ S. Trefin İleostomi Tecrübemiz. Turk J Surg 2011;27:174-175.

8. MacCormack BJ, McCallion WA. Colonoscopic assisted trephine stoma in children with chronic constipation. Ann R Coll Surg Engl 2014;96:387388.

9. Nguyen MH, Pittas F. How large should a skin trephine be for an end stoma? Aust N Z J Surg 1999;69:675-676.

10. Caruso DM, Kassir AA, Robles RA, Gregory MW, Tsujimura RB, Cheung $P$ et al. Use of trephine stoma in sigmoid volvulus. Dis Colon Rectum 1996;39:1222-1226.

11. Hellinger MD, Al Haddad A. Minimally invasive stomas. Clin Colon Rectal Surg 2008;21:53-61.

12. Nylund G, Oresland T, Hultén L. The trephine stoma: formation of a stoma without laparotomy. Eur J Surg 1997 Aug;163:627-629.

13. Kini SU, Perston Y, Radcliffe AG. Laparoscopically assisted trephine stoma formation. Surg Laparosc Endosc 1996;6:371-4. 